\title{
Riverine and riparian clitellates of three drainages in southern Sweden
}

\author{
C. Erséus $1,2 *$, E. Rota ${ }^{3}$, T. Timm ${ }^{4}$, R. Grimm ${ }^{5}$, B. Healy ${ }^{6}$, S. Lundberg ${ }^{1}$
}

\author{
${ }^{1}$ Department of Invertebrate Zoology, Swedish Museum of Natural History, Box 50007, SE-104 05 Stockholm, Sweden \\ 2 Current address : Department of Zoology, Göteborg University, Box 463, SE-405 30 Göteborg, Sweden. \\ ${ }^{3}$ Dipartimento di Scienze Ambientali, Università di Siena, Via P. A. Mattioli 4, IT-53100 Siena, Italy \\ 4 Võrtsjärv Limnological Station, Institute of Zoology and Botany, Estonian Agricultural University, EE-61101 Rannu, Tartumaa, Estonia \\ 5 Zoologisches Institut und Zoologisches Museum, Universität Hamburg, Martin-Luther-King-Platz 3, DE-20146 Hamburg, Germany \\ ${ }^{6}$ Department of Zoology, University College, Belfield, Dublin 4, Ireland
}

\begin{abstract}
The species diversity of Clitellata (a group of annelid worms) is described for three river systems in different parts of southern Sweden. The water of one river (Säveån) discharges into the harbour of Göteborg on the Swedish west coast, that of the other two rivers (Svartån and Kilaån) into the Baltic Sea. A total of 143 species, representing the taxa Enchytraeidae (61), Propappidae (1), Lumbricidae (15), Lumbriculidae (6), Tubificidae (4 Rhyacodrilinae, 33 Naidinae, 13 Tubificinae), and Hirudinida (10), are reported. Of these, 24 enchytraeids and six lumbricids were found only in the riparian zone, i.e., in the semiaquatic habitats of the river banks. Six species of Enchytraeidae could not be assigned to any known species and are likely to be new to science. In addition, the following species are recorded from Sweden for the first time : Achaeta brevivasa, Fridericia benti, F. healyae, F. lenta, F. sylvatica, Oconnorella tubifera (all Enchytraeidae), Aporrectodea limicola (Lumbricidae), Stylodrilus brachystylus (Lumbriculidae), Dero dorsalis, Nais behningi, Haber speciosus, and Peipsidrilus ?saamicus (all Tubificidae). Overall, the species composition is typical of today's fauna of the once glaciated Northern Europe, but for the family Enchytraeidae, the biogeographical affinity of Sweden is stronger with Denmark and Germany than with, e.g., the British Isles and the eastern parts of Central Europe.
\end{abstract}

Keywords : Clitellata, species diversity, river fauna, riparian zone, Sweden, biogeography.

\section{Introduction}

The present fauna of freshwater and terrestrial clitellates in Sweden is the result of an accumulation of species, all of which are likely to have have colonized the country within the last about 10,000 years, i.e., since the last glaciation, when the country was completely covered by continental ice; it is improbable that any metazoans survived Pleistocene glaciations in Sweden, while trans-glacial elements may have occurred in more western parts of North Europe (see Kristjánsson \& Svavarsson 2004, Wood \& Proudlove 2004). However, as this time is short in a geological perspective, it

\footnotetext{
* Corresponding author : E-mail : christer.erseus@zool.gu.se
}

is likely that the species diversity is still on the rise and has not yet reached its saturation. There is evidence that some species have arrived in Sweden rather recently. For instance, the thermophilous Branchiura sowerbyi Beddard, 1892, the North American Limnodrilus cervix Brinkhurst, 1963, and some Ponto-Caspian Potamothrix species (all Tubificidae), and the exotic earthworms Dichogaster bolaui (Michaelsen, 1891) and D. saliens (Beddard, 1893), all appear to have been established in Sweden during the $20^{\text {th }}$ century (Milbrink 1980, 1999, Milbrink \& Timm 2001, Erséus et al. 1994, Timm et al. 1997).

The distributional records confirm that the clitellates of Sweden are largely recruited from the eastern and middle parts of Europe, and this probably holds true even for taxa that originally evolved outside Europe, 
but it is not known exactly how many species have already made it across the Baltic Sea. Even less is known about how far different species have advanced along or across the Scandinavian Peninsula. The profundal, and to some extent the littoral, oligochaetous clitellates of the large lakes of southern Sweden have been relatively well studied, in particular by Milbrink (1969, 1970, 1973, 1978), and for some species of Potamothrix, even a trend of ongoing dispersal from eastern (Lake Mälaren) to western drainages has been noted (Milbrink 1993, 1999, Milbrink \& Timm 2001). Moreover, Milbrink et al. (2002) have compiled faunistic information on clitellates from a great number of smaller and medium-sized lakes representing many parts of the country, and other more erratic records of freshwater species have been given by Timm et al. (1997), and Erséus et al. (1999). Finally, for the terrestrial Enchytraeidae and Lumbricidae, some recent studies have increased the number of species reported from Sweden considerably (Chalupsky 1992, Rota \& Erséus 1997, Rota et al. 1998, Rota \& Healy 1999). Still, however, to this point there has been no comparable study of the clitellate fauna associated with rivers and riparian habitats in this country.

The aim of the present paper is to describe the overall species diversity of Clitellata from three Swedish river systems (Säveån, Svartån and Kilaån). It is a first attempt to assess this riverine fauna in southern Sweden and to put it into a context of European freshwater biogeography in the broader sense. Lentic and lotic habitats in the open parts of the watercourses, as well as the fringing riparian zones of the three rivers were surveyed. The riparian zones, which contain the interfaces between soil and water, have been considered as being "among the most diverse, dynamic, and complex biophysical habitat on the terrestrial portion of the Earth" (Bardgett et al. 2001, p. 422, Naiman \& Décamps 1997). They are therefore important for the functioning of the riverine ecosystems, and not the least for smaller streams.

\section{Study area}

Three medium-sized rivers were selected to represent different drainages in southern Sweden (Fig. 1). Säveån River (about $57.9^{\circ} \mathrm{N}, 12.5^{\circ} \mathrm{E}$ ), in the province of Västergötland, is the lowermost tributary to the Göta River and enters into the latter immediately inside the harbour of Göteborg (i.e., the Göta estuary), on the Swedish west coast. Göta is the largest river system in southern Sweden; it even covers parts of eastern Norway. Säveån, with a length of about $130 \mathrm{~km}$, drains an area of $1,484 \mathrm{~km}^{2}$, which is only $3 \%$ of the total Göta watershed area. The upper and lower courses of Säveån are located in hilly woodlands, whereas the middle course flows more slowly through an agricultural area and receives large amounts of nutrients. Immediately downstream of the middle course, however, the river passes through Lake Mjörn, which is large enough to act as a purification basin reducing the load of organic pollution considerably before the water reaches the lower course. Over $10 \%$ of the total drainage areas are lakes. Our sampling was confined to the upper and lower courses of Säveån, including some stream tributaries, and at all stations the water was clear and without evidence of pollution.

Svartån River (about $59.3^{\circ} \mathrm{N}, 15.0^{\circ} \mathrm{E}$ ) runs through the province of Närke, in the centre of the country. It includes two main branches, the longer one being about $80 \mathrm{~km}$ long. The whole river system drains an area of $1,352 \mathrm{~km}^{2}$. The effluent of the lower end of the river enters Lake Hjälmaren at the city of Örebro, and via this lake, and Lake Mälaren further downstream, reaches the Baltic Sea through two outlets, one at Södertälje and one at Stockholm. As Hjälmaren and Mälaren are the fourth and third largest lakes in Sweden, respectively, Svartån is (like Säveån) part of a relatively large drainage system, but it represents an upper part of this system, i.e., it is located more inland from the coast than Säveån. The headwaters are pristine hill streams, some of which harbour populations of Margaritifera margaritifera L., 1758 (freshwater pearl mussels), but downstream the river becomes rather heavily loaded with sediment and nutrients, due to intensive farming along its banks. Most of the collecting in Svartån was done in or near the rapids at Karlslund, in a reach where the river has attained its maximum pollution level, and which is immediately upstream of the city of Örebro.

The third watercourse, Kilaån River (about $58.7^{\circ} \mathrm{N}$, $16.5^{\circ} \mathrm{E}$ ), discharges directly into the Baltic Sea at the city of Nyköping, about $100 \mathrm{~km} \mathrm{SW}$ of Stockholm. It starts as two second order tributaries, Ålbergaån River (in the north) and Vretaån River (in the south), which meet to form the lower reach, the Kilaån proper. These three main branches together are about $50 \mathrm{~km}$ long and drain most of the southern part of the province of Södermanland, with some of the uppermost tributaries located in the province of Östergötland. The whole drainage area is $432 \mathrm{~km}^{2}$ and consists mainly of coniferous forests (about 70\%). Boglands make up another 6\%, and 65 lakes sized more than 1 hectare hold $4 \%$ of the total drainage. Material was collected at sites distributed over a great part of the river system. 


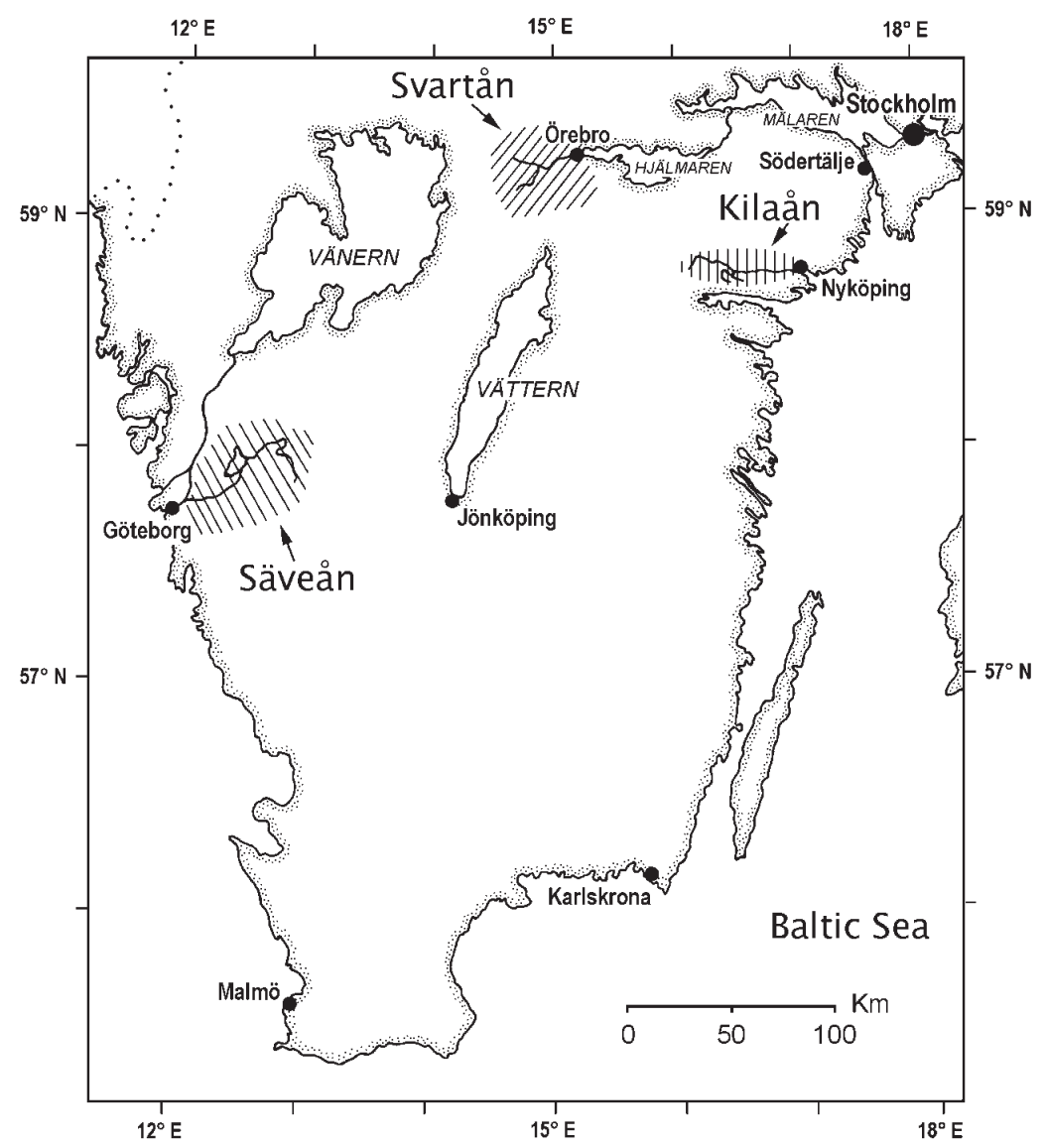

Fig. 1 Map of southern Sweden showing the location of the three studied rivers.

\section{Material and methods}

Clitellate worms were collected over a period of two years during 1996-1998 : Svartån was visited in September 1996 (1 day) and August 1998 (1 day); Säveån in June 1997 (5 days); and Kilaån in August 1998 (3 days). Detailed information about the sampling sites and the distribution of species at all these are given in a number of unpublished reports compiled by different constellations of the present authors, and all available in the library of the Department of Invertebrate Zoology, Swedish Museum of Natural History (SMNH). Emilia Rota and Brenda Healy are responsible for most of the enchytraeid collection and identification; E. Rota also collected and identified the lumbricids. Tarmo Timm identified a majority of the freshwater taxa (lumbriculids, tubificids, 'naidids', leeches), while Reinmar Grimm collected and identified most of the 'naidids' from Svartån and Kilaån Rivers. Some leech data were also provided by Dr. Mark E. Siddall (Ame- rican Museum of Natural History, New York), who participated in the field work at Kilaån for one day. In the present paper, the distributional records are largely summarized as species occurring in each river system, but the sampling sites were separated into two habitat groups, one regarded as "aquatic" (AQU in Table 1), the other as "riparian" (RIP in Table 1).

Sampling was qualitative rather than quantitative, in the aquatic habitats involving kick sampling (Hynes 1970), various methods of netting among aquatic plants and soft detrital sediments, and digging, followed by decantation of organic material suspended in water into a fine mesh $(0.25 \mathrm{~mm})$ sieve. Riparian, i.e., semi-aquatic, sand, soil and vegetation (roots), dug out from the river banks, were brought to the laboratory, and worms were extracted from the samples using the wet-funnel method (O'Connor 1955, Healy \& Rota 1992). River-bank earthworms were collected by hand while digging or turning over rocks, logs, etc. 
Table 1. Clitellate species recorded from Säveån, Svartån and Kilaån Rivers in southern Sweden. Occurrences are separated into aquatic (AQU) and riparian (RIP) habitats. Species previously not recorded from Sweden are noted by an asterisk $(*)$. Species occurring in all three rivers in boldface letters.

\begin{tabular}{llll}
\hline & SÄVEÅN & SVARTAN KILÅ̊N \\
& AQU RIP & AQU RIP AQU RIP \\
\hline
\end{tabular}

\section{ENCHYTRAEIDAE}

Achaeta aberrans Nielsen \& Christensen, 1961

Achaeta bibulba Graefe, 1989

* Achaeta brevivasa Graefe, 1980

Achaeta camerani (Cognetti, 1899)

Achaeta eiseni (Vejdovský, 1878)

*Achaeta sp.n.

Bryodrilus ehlersi Ude, 1892

Buchholzia appendiculata (Buchholz, 1862)

Cernosvitoviella aggtelekiensis Dózsa-Farkas, 1970

Cernosvitoviella ampullax (Klungland \& Abrahamsen, 1981)

Cernosvitoviella atrata (Bretscher, 1903)

Cernosvitoviella microtheca Rota \& Healy, 1999

Cernosvitoviella minor (Dózsa-Farkas, 1990)

*Cernosvitoviella sp. $\mathrm{n}$. \# 1

*Cernosvitoviella sp. $\mathrm{n}$. \#2

$\left({ }^{*}\right)$ Cernosvitoviella $\mathrm{sp}$. indet. (sp. n. \#3?)

Cognettia glandulosa (Michaelsen, 1888)

Cognettia sphagnetorum (Vejdovský, 1878)

Cognettia sp. sensu Chalupský, 1992

Enchytraeus buchholzi Vejdovský, 1878 s.l.

Enchytraeus bulbosus Nielsen \& Christensen, 1963

Enchytraeus christenseni christenseni Dózsa-Farkas, 1992

Enchytraeus lacteus Nielsen \& Christensen, 1961

Enchytraeus norvegicus Abrahamsen, 1969

Enchytronia parva Nielsen \& Christensen, 1959 s.l.

*Fridericia benti Schmelz, 2002

Fridericia bisetosa (Levinsen, 1884)

Fridericia bulboides Nielsen \& Christensen, 1959 s.l.

Fridericia christeri Rota \& Healy, 1999

Fridericia connata Bretscher, 1902

Fridericia deformis Möller, 1971

Fridericia galba (Hoffmeister, 1843)

*Fridericia healyae Schmelz, 2003

Fridericia isseli Rota, 1994

*Fridericia lenta Schmelz, 2003

Fridericia nemoralis Nurminen, 1970

Fridericia paroniana Issel, 1904

Fridericia perrieri (Vejdovský, 1878)

Fridericia ratzeli (Eisen, 1872) s.l.

Fridericia sohlenii Rota, Healy \& Erséus, 1999

Fridericia striata (Levinsen, 1884)

*Fridericia sylvatica Healy, 1979

Fridericia waldenstroemi Rota \& Healy, 1999

(*)Fridericia sp. indet.(sp. n.?)

Hemifridericia parva Nielsen \& Christensen, 1959

\begin{tabular}{llllll} 
& RIP & - & - & AQU & RIP \\
- & RIP & - & - & - & RIP \\
- & - & - & - & - & RIP \\
- & RIP & - & - & AQU & RIP \\
- & - & - & - & - & RIP \\
AQU & RIP & - & RIP & - & RIP \\
AQU & - & - & - & - & - \\
- & RIP & - & - & AQU & RIP \\
AQU & - & - & - & AQU & RIP \\
- & - & - & - & AQU & - \\
AQU & RIP & - & - & AQU & RIP \\
AQU & RIP & - & - & AQU & RIP \\
AQU & RIP & - & - & AQU & - \\
- & - & - & - & AQU & RIP \\
- & - & - & - & - & RIP \\
AQU & - & - & - & - & - \\
AQU & RIP & AQU & - & AQU & RIP \\
AQU & - & AQU & - & AQU & RIP \\
AQU & RIP & - & - & - & - \\
AQU & RIP & - & - & AQU & RIP \\
\hline & RIP & - & - & - & - \\
AQU & RIP & - & - & AQU & RIP \\
- & - & - & - & - & RIP \\
- & RIP & - & - & - & RIP \\
- & RIP & - & RIP & - & RIP \\
- & - & - & RIP & - & RIP \\
- & RIP & - & - & AQU & - \\
AQU & RIP & - & - & AQU & RIP \\
- & - & - & - & - & RIP \\
- & RIP & - & - & AQU & RIP \\
- & - & - & - & - & RIP \\
AQU & RIP & AQU & - & AQU & RIP \\
AQU & RIP & - & - & - & - \\
- & - & - & - & - & RIP \\
- & - & - & - & - & RIP \\
- & - & - & - & - & RIP \\
- & RIP & - & RIP & - & RIP \\
AQU & RIP & AQU & RIP & AQU & RIP \\
AQU & RIP & AQU & RIP & AQU & RIP \\
- & RIP & AQU & - & - & - \\
AQU & - & - & - & - & - \\
- & RIP & - & - & - & - \\
- & - & - & RIP & - & RIP \\
- & RIP & - & - & - & - \\
& RIP & - & - & AQU & RIP
\end{tabular}


Table 1. (Continued).

\begin{tabular}{|c|c|c|c|c|c|c|}
\hline & \multicolumn{2}{|c|}{ SÄVEÅN } & \multicolumn{2}{|c|}{ SVARTÅN } & \multicolumn{2}{|c|}{ KILAÅN } \\
\hline & $\mathrm{AQU}$ & RIP & $\mathrm{AQU}$ & RIP & $\mathrm{AQU}$ & RIP \\
\hline Henlea perpusilla Friend, 1911 & AQU & RIP & - & RIP & AQU & RIP \\
\hline Henlea ventriculosa (d'Udekem, 1854) & - & RIP & $\mathrm{AQU}$ & - & - & \\
\hline Marionina argentea (Michaelsen, 1889) & $\mathbf{A Q U}$ & RIP & AQU & - & AQU & RIP \\
\hline Marionina communis Nielsen \& Christensen, 1959 & - & RIP & - & - & $-\infty$ & - \\
\hline Marionina filiformis Nielsen \& Christensen, 1959 & - & RIP & - & - & $\mathrm{AQU}$ & RIP \\
\hline Marionina riparia Bretscher, 1899 & $\mathrm{AQU}$ & - & AQU & - & - & - \\
\hline Marionina simillima Nielsen \& Christensen, 1959 & $\mathrm{AQU}$ & RIP & - & - & - & - \\
\hline${ }^{*}$ Marionina sp.n. & $\mathrm{AQU}$ & RIP & - & - & - & RIP \\
\hline Mesenchytraeus armatus (Levinsen, 1884) & $\mathbf{A Q U}$ & RIP & AQU & - & AQU & RIP \\
\hline Mesenchytraeus beumeri (Michaelsen, 1886) & - & - & AQU & - & - & - \\
\hline Mesenchytraeus flavus (Levinsen, 1884) & - & RIP & - & - & - & - \\
\hline Mesenchytraeus glandulosus (Levinsen, 1884) & - & - & - & - & - & RIP \\
\hline Mesenchytraeus pelicensis Issel, 1905 & - & - & - & - & - & RIP \\
\hline Oconnorella cambrensis (O'Connor, 1963$)$ & AQU & RIP & - & - & - & - \\
\hline *Oconnorella tubifera (Nielsen \& Christensen, 1959) & - & RIP & - & - & - & - \\
\hline Stercutus niveus Michaelsen, 1888 & - & RIP & - & RIP & - & - \\
\hline \multicolumn{7}{|l|}{ PROPAPPIDAE } \\
\hline Propappus volki Michaelsen, 1914 & - & - & $\mathrm{AQU}$ & - & - & - \\
\hline \multicolumn{7}{|l|}{ LUMBRICIDAE } \\
\hline Allolobophora chlorotica (Savigny, 1826) & $\mathrm{AQU}$ & RIP & - & - & - & - \\
\hline Aporrectodea caliginosa (Savigny, 1826) s.l. & $\mathbf{A Q U}$ & RIP & AQU & RIP & - & RIP \\
\hline${ }^{*}$ Aporrectodea limicola (Michaelsen, 1890 ) & & RIP & - & - & - & - \\
\hline Aporrectodea longa (Ude, 1885) & - & RIP & $\mathrm{AQU}$ & RIP & - & - \\
\hline Aporrectodea rosea (Savigny, 1826) & AQU & RIP & AQU & RIP & AQU & RIP \\
\hline Dendrobaena attemsi (Michaelsen, 1902) & - & RIP & - & - & - & - \\
\hline Dendrobaena octaedra (Savigny, 1826) & - & RIP & AQU & - & - & RIP \\
\hline Dendrodrilus rubidus (Savigny, 1826) & AQU & RIP & - & RIP & AQU & RIP \\
\hline Eiseniella tetraedra (Savigny, 1826) & $\mathbf{A Q U}$ & RIP & AQU & RIP & $\mathbf{A Q U}$ & RIP \\
\hline Lumbricus castaneus (Savigny, 1826) & - & RIP & - & RIP & - & RIP \\
\hline Lumbricus festivus (Savigny, 1826) & - & RIP & - & - & - & - \\
\hline Lumbricus rubellus Hoffmeister, 1843 & - & RIP & - & RIP & - & RIP \\
\hline Lumbricus terrestris Linnaeus, 1758 & - & - & - & RIP & - & RIP \\
\hline Octolasion cyaneum (Savigny, 1826) & $\mathrm{AQU}$ & RIP & $\mathrm{AQU}$ & - & - & - \\
\hline Octolasion lacteum (Örley, 1881) & $\mathbf{A Q U}$ & RIP & AQU & RIP & - & RIP \\
\hline \multicolumn{7}{|l|}{ LUMBRICULIDAE } \\
\hline Lumbriculus variegatus (Müller, 1773) & $\mathbf{A Q U}$ & - & $\mathrm{AQU}$ & - & AQU & - \\
\hline Rhynchelmis limosella Hoffmeister, 1843 & - & - & $\mathrm{AQU}$ & - & - & - \\
\hline Rhynchelmis tetratheca Michaelsen, 1920 & AQU & - & $\mathbf{A Q U}$ & - & AQU & - \\
\hline Stylodrilus heringianus Claparède, 1862 & $\mathbf{A Q U}$ & - & AQU & - & AQU & - \\
\hline *Stylodrilus brachystylus Hrabe, 1929 & - & - & - & - & $\mathrm{AQU}$ & - \\
\hline Trichodrilus sp. & - & - & - & - & $\mathrm{AQU}$ & - \\
\hline \multicolumn{7}{|l|}{ TUBIFICIDAE, RHYACODRILINAE } \\
\hline Bothrioneurum vejdovskyanum Štolc, 1888 & $\mathrm{AQU}$ & - & $\mathrm{AQU}$ & - & - & - \\
\hline Rhyacodrilus coccineus (Vejdovský, 1875) & $\mathbf{A Q U}$ & - & $\mathrm{AQU}$ & - & AQU & - \\
\hline Rhyacodrilus falciformis Bretscher, 1901 & $\mathrm{AQU}$ & - & - & - & $\mathrm{AQU}$ & - \\
\hline Rhyacodrilus subterraneus Hrabě, 1963 & $\mathrm{AQU}$ & - & $A Q U$ & - & - & - \\
\hline \multicolumn{7}{|c|}{ TUBIFICINAE, NAIDINAE (formerly referred to as family NAIDIDAE) } \\
\hline Allonais sp. & - & - & - & - & $\mathrm{AQU}$ & - \\
\hline Chaetogaster cristallinus Vejdovský, 1883 & $\mathrm{AQU}$ & - & - & - & - & - \\
\hline Chaetogaster diaphanus (Gruithuisen, 1828) & $\mathbf{A Q U}$ & - & AQU & - & $\mathbf{A Q U}$ & - \\
\hline Chaetogaster diastrophus (Gruithuisen, 1828) & $\mathbf{A Q U}$ & - & $\mathbf{A Q U}$ & - & $\mathbf{A Q U}$ & - \\
\hline Chaetogaster langi Bretscher, 1896 & $\mathbf{A Q U}$ & - & $\mathbf{A Q U}$ & - & $\mathbf{A Q U}$ & - \\
\hline Chaetogaster limnaei Baer, 1827 & - & - & $\mathrm{AQU}$ & - & & - \\
\hline Dero digitata (Müller, 1773) & - & - & $\mathrm{AQU}$ & - & $\mathrm{AQU}$ & - \\
\hline
\end{tabular}


Table 1. (Continued).

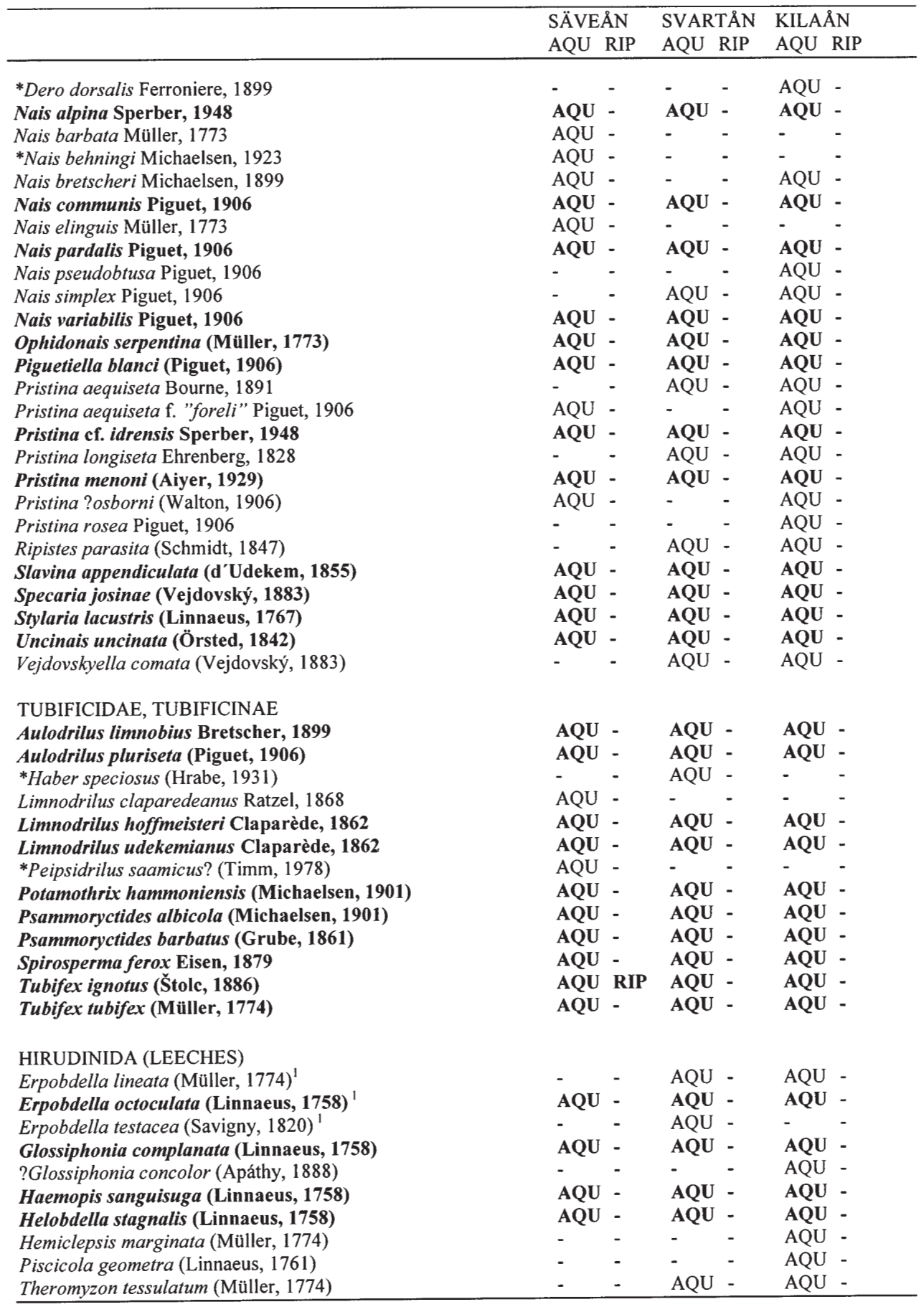

${ }^{1}$ Nomenclature following Siddall, 2002. 
The aquatic worms were fixed in formalin (and later transferred into 70-80\% alcohol) or preserved directly in alcohol. Subsequently, they were either directly identified under a dissection microscope, or cleared in a drop of glycerine under a coverslip and examined in a compound microscope. A majority of the enchytraeid worms were examined microscopically while alive; most mature specimens could be identified to species without further treatment. However, representatives of many taxa were relaxed in $10 \%$ alcohol and fixed in Bouin's fluid, Kahle's fluid or $70 \%$ alcohol, to enable further taxonomic assessment in future work. Earthworms were relaxed in water with addition of alcohol and finally killed and preserved in 70-80\% alcohol; specimens of partial or full sexual maturity were subsequently identified in their preserved state.

\section{Results}

\section{Species diversity}

A total of 143 clitellate species (Tables 1-2) were identified in the material from the three rivers. Of these 103 were found in Säveån, 77 in Svartån, and 106 in Kilaån. Fifty-two (36\%) of all species were recorded from all three rivers. The low number for Svartån is largely due to its poor representation of enchytraeids, most likely explained by the limited effort regarding riparian samples from this river; such samples were only collected on one occasion (26 Aug 1998). If the enchytraeids are excluded, $41(50 \%)$ out of a totally 82 species were collected from all rivers.

Although the actual composition of species varies between the rivers, the number of recorded species is similar for all groups except Enchytraeidae (see Tables 1-2 for details). Moreover, in pairwise comparisons of all rivers (Table 2), and again excluding Enchytraeidae, Svartån and Kilaån are more similar to each other than any of them is to Säveån; the two rivers share 50 non-enchytraeid species, and this is largely attributed to the relatively high number of shared naidines and hirudinidans. Due to the sampling design, however, it cannot be determined whether this is statistically significant.

\section{Faunistics and Taxonomy}

A large part, $61(43 \%)$ of the 143 species found belong to Enchytraeidae, a family commonly regarded as terrestrial, but which, as shown in Table 1 (61\% of the species were collected in water), is well represented also in open aquatic habitats, as well as in groundwater and in partially-to-well saturated wet soils characteristic of the riparian zone. Among the 61 recorded enchytraeid species, only 49 were previously known from Sweden, and of the 12 new records, only six species could be attributed to named taxa: Achaeta brevivasa Graefe, 1980, Fridericia benti Schmelz, 2002, F. healyae Schmelz, 2003 (= F. polychaeta Bretscher sensu Southern 1907), F. lenta Schmelz, 2003 [= F. leydigi (Vejdovsky) sensu Nielsen \& Christensen 1959; see Schmelz 2003], F. sylvatica Healy, 1979 (= F. miraflores Sesma \& Dózsa-Farkas, 1993; see Schmelz 2003), and Oconnorella tubifera (Nielsen \& Christensen, 1959) (=O. chalupskyi Rota, 1995; see DózsaFarkas 2002). For additional taxonomic comments, see Discussion. The remaining enchytraeids of this study appear to represent up to six species new to science. Some of them will be described separately (Rota \& Er-

Table 2. Summary of species diversity of higher clitellate taxa in Säveån (Säv), Svartån (Sva) and Kilaån (Kil) Rivers in southern Sweden, comparing the number of species found from the different rivers.s

\begin{tabular}{lccccccccc}
\hline Taxon & Total & Säv & Sva & Kil & All 3 Säv+Sva Sva+Kil Säv+Kil \\
\hline Enchytraeidae & 61 & 44 & 18 & 43 & 11 & 15 & 13 & 28 \\
Propappidae & 1 & - & 1 & - & - & - & - & - \\
Lumbricidae & 15 & 14 & 11 & 9 & 8 & 10 & 9 & 8 \\
Lumbriculidae & 6 & 3 & 4 & 5 & 3 & 3 & 3 & 3 \\
Tubificidae, Rhyacodrilinae & 4 & 4 & 3 & 2 & 1 & 3 & 1 & 2 \\
Tubificidae, Naidinae & 33 & 22 & 22 & 28 & 15 & 15 & 21 & 18 \\
Tubificidae, Tubificinae & 13 & 12 & 11 & 10 & 10 & 10 & 10 & 10 \\
Hirudinida & 10 & 4 & 7 & 9 & 4 & 4 & 6 & 4 \\
\hline All taxa & 143 & 103 & 77 & 106 & 52 & 60 & 63 & 72 \\
(All excl. Enchytraeidae) & $(82)$ & $(59)$ & $(59)$ & $(63)$ & $(41)$ & $(45)$ & $(50)$ & $(45)$ \\
\hline
\end{tabular}


séus, in preparation; Rota, in preparation).

As already reported by Timm et al. (1997), a single species of Propappidae, Propappus volki Michaelsen, 1914, was collected in Svartån River.

In this study, 15 species of Lumbricidae were found (Table 1-2). One of them, Aporrectodea limicola (Michaelsen, 1890), encountered at one riparian site at Säveån River, has never been found in Sweden before. An old record of this species from Uppåkra in Skåne (Berlin 1923) was subsequently withdrawn as wrong by its author (see Julin 1949, p. 25). Moreover, Dendrobaena attemsi (Michaelsen, 1902), a largely Central and Southeastern European earthworm, but once also recorded from Stockholm, Sweden (Rota \& Erséus, 1997), was collected close to the outlet of Säveån River in Lake Aspen, at Lerum. These new records will be treated in more detail elsewhere (Rota \& Erséus, in preparation).

Lumbriculidae is a truly aquatic family with few species reported from Sweden to date. Six taxa were found in this study, including Stylodrilus brachystylus Hrabe, 1929 (a new record for Sweden), and an unidentified Trichodrilus sp., both from Kilaån River. So far, no other Trichodrilus than T. allobrogum Claparède, 1862 had been noted to occur in the country (Holmquist 1975).

The remaining oligochaetous clitellates of our study are all members of Tubificidae, following the recent proposal by Erséus \& Gustavsson (2002) to regard the former "Naididae" as a subfamily, Naidinae, within that family. Among a total of 50 recorded tubificid species, $33(67 \%)$ are naidines. Two species of Naidinae, Dero dorsalis Ferronière, 1899 (collected in Kilaån), and Nais behningi Michaelsen, 1923 (in Säveån), and two species of Tubificinae, Haber speciosus (Hrabe, 1931) (collected in Svartån), and a taxon preliminary identified as Peipsidrilus saamicus (Timm, 1978) (in Säveån), are new records for Sweden.

A total of ten leech species (Hirudinida) were identified from the three rivers. All are previously known from the country. The knowledge of leeches in Sweden has never been properly and completely reviewed, although there is a comprehensive account of the Danish leech fauna (Kirkegaard 1985). A recent compilation made by the Swedish Species Information Centre (Dr. U. Gärdenfors, personal communication) lists a total of about 15 freshwater species from Sweden, but additional species may occur.

To summarize, twelve species of Enchytraeidae (up to six of which new to science), one of Lumbricidae, one of Lumbriculidae, and four of Tubificidae (inclu- ding Naidinae) are new records for Sweden.

\section{Habitat}

The addition of riparian samples yielded 24 species of Enchytraeidae and six species of Lumbricidae not encountered in any of the "aquatic" samples (see Table 1), while 31 enchytraeids and nine lumbricids were present in riparian as well as aquatic sites. Only six enchytraeid taxa were exclusively collected in the truly aquatic habitat (Bryodrilus ehlersi, Cernosvitoviella ampullax, $C$. sp. indet., Fridericia striata, Marionina riparia, Mesenchytraeus beumeri), but most of these had only a single occurrence in one river.

Although none was exclusively aquatic, only six out of the 15 earthworm species (Lumbricidae) were restricted to the riparian zone. However, aquatic occurrences of lumbricids may be accidental (see Discussion).

All species (except Tubifex ignotus) of the remaining groups (Propappidae, Lumbriculidae, Tubificidae, Hirudinida) were confined to the proper aquatic habitats.

\section{Discussion}

\section{Enchytraeidae}

Fridericia benti was encountered by us also during the survey of Nationalstadsparken in Stockholm but identified as F. bulbosa (Rosa, 1887) (see Erséus et al. 1999), following Nielsen \& Christensen's (1959) confusing taxonomy of the latter. All our material of $F$. benti fits the original description (Schmelz 2002) except for the size of the spermatozoa which appear much shorter than $210 \mu \mathrm{m}$. In a subsequent work, however, Schmelz (2003, pp. 116-117, fig. 17B) figures the sperm heads as being half the length given in the text ("ca. $75 \mu \mathrm{m}$ "). The deviation of our material may thus be only apparent and due to an incorrect calculation in Schmelz's primary account. The same author (Schmelz 2003) recently proposed to synonymise Fridericia sohlenii Rota et al., 1998 with the bisetose Australian F. cylindrica Springett, 1971, based on a reexamination of the types of the latter and the observed correspondence in the shape of the male openings and the pattern (but not the size) of the clitellar glands, as well as the general structure of the clitellum and spermathecae. The similarity of less trivial features diagnostic of $F$. sohlenii, such as the peripheral granulation of the coelomocytes (in vivo), the number of preclitellar nephridia, the granular wall of the spermathecal ampullae, the heterogeneous texture of the sperm funnels, the length of the chaetae, the rosette of gland 
cells at the male pore (see Rota et al. 1998) was impossible to verify, partly because those features are best observable in vivo. [In this context, Schmelz (2003, p. 175) speculates about the possibly similar texture of the coelomocytes, which would have caused a "yellowish tint of the body colour" in both the Australian and the European live specimens. However, nowhere did Springett (1971) mention a yellowish tint for $F$. cylindrica.] Besides, we think several traits of $F$. cylindrica (the shorter brain, the different structure of the spermathecal duct, the occurrence of sperm in the ampullar lumen, the absence of chylus cells in preclitellar segments, and the unusually long peptonephridia (reaching segment VII) and sperm funnels (described by Springett as "3-5 times longer than broad") speak against its being conspecific with $F$. sohlenii. Thus, in the light of the inadequate comparison and incomplete matching of the examinable features, we consider Schmelz's taxonomic decision too weakly supported to be acceptable.

Enchytraeidae is often regarded as a primarily terrestrial group, but it is probably the most ubiquitous of all clitellate families, with its more extreme habitats including glacial ice and deep-sea sediments (Erséus 2005). In the present study, the amphibious nature of many enchytraeid species is manifested, and the inclusion of the riparian zone does not only demonstrate that many enchytraeids prefer wet habitats, it also emphasizes the importance of the river banks in estimating the total species diversity of a river system.

The known enchytraeids of terrestrial and freshwater habitats in Sweden are representative of a northern Central European fauna. About $90 \%$ of the about 80 recorded species are found also in Denmark and/or Germany. The rest of the Swedish fauna (8 species) are either characteristic of saturated substrates such as bogs, marshes, and margins of lakes and rivers, which are poorly investigated outside Fennoscandia and the British Isles (Cernosvitoviella spp.), or Arctic Alpine elements (Bryodrilus parvus Nurminen, 1970, Henlea glandulifera Nurminen, 1970), or species strictly confined to the higher latitudes of Fennoscandia and Russia (Cognettia lapponica Nurminen, 1965). The affinities of the Swedish fauna diminish remarkably when considering comparably well-studied but more distant countries of Western, Eastern and southern Central Europe: $65 \%$ of the species are shared with the British Isles, $60 \%$ with the Czech and Slovak Republics and/or Poland, only about $50 \%$ with Italy and Hungary.

The greater part of the enchytraeids common to Sweden and the neighbouring European mainland have a wide distribution, but there are three small groups of species which may contain true middle, western or eastern European elements: (1) Achaeta brevivasa, Fridericia sohlenii and $F$. ulrikae appear to be confined to Sweden, Denmark and Germany. (2) Achaeta aberrans, Fridericia christeri, F. healyae and Marionina filiformis occur in Ireland, Great Britain and/or France and Portugal but are so far unknown from the area east of Germany. (3) Fridericia nemoralis, F. singula and $F$. waldenstroemi are so far only known from middleeastern Europe. The biogeography of Fridericia nemoralis is particularly interesting; it may be an exception to the preferential postglacial route of repopulation of Scandinavia via Denmark and Germany: this species lives in Germany, Czech Republic, Hungary, Estonia, Finland and Sweden, but it has never been found in Denmark. Like F. healyae, F. sohlenii and F. christeri, $F$. nemoralis is frequently found in wet to damp soils at the edge of rivers (Rota \& Healy 1999, Rota et al. 1998, Schmelz 2003).

\section{Other taxa}

The more typically aquatic clitellate fauna (Tubificidae, Lumbriculidae, Propappidae and Hirudinida) of the rivers studied consists mainly of species known also from Finland, Karelia, Estonia, and other parts of Northern Europe, and it can be concluded that most of them have spread spontaneously throughout this region after the last glaciation (Timm 1987 Popcenko 1988). At the same time, however, our study seems to corroborate that there still is a diverse tubificid and lumbriculid fauna endemic to Central Europe [e.g., Embolocephalus velutinus (Grube, 1879), Nais stolci Hrabe, 1981, Stylodrilus lemani (Grube, 1879), and many others] that has failed to reach Sweden over the former land bridge from Denmark and Germany. $\mathrm{Ha}$ ber speciosus, now recorded from Svartån (present study), and the recent findings of Rhyacodrilus subterraneus Hrabe, 1963 in Sweden as well as Norway (Timm et al. 1997) may serve as exceptions to this pattern. Several other, largely groundwater-bound species originally described from Central Europe, such as Rhyacodrilus falciformis Bretscher, 1901, and Stylodrilus brachystylus, were later found both in Scandinavia and Northeastern Europe (Ekman 1915, Piguet 1919, Timm 1987, Popcenko 1988). However, it is remarkable that $R$. falciformis, now repeatedly recorded from wet soils both in Sweden and elsewhere (Timm et al. 1997, Erséus et al. 1999, Brinkhurst 1978, 1986), was not found in the river-banks of the present study. Thus, its distribution in groundwaters may be more limited than suggested by the previous, widely dispersed records (including also North America). 
The Ponto-Caspian anthropochorous invaders of the genus Potamothrix, found in some localities of Sweden (Milbrink 1999, Milbrink \& Timm 2001), were not found in the three rivers under study. They appear not to have reached these waters yet, supporting the hypothesis that their spread is associated with river navigation (Timm 1987). Potamothrix hammoniensis, the only representative of this genus recorded here, is probably an early, spontaneous post-glacial invader in northern Europe. It does not seem to be as easily dispersible by man as are $P$. moldaviensis Vejdovsky \& Mrázek, 1902 and P. vejdovskyi (Hrabe, 1941). For instance, the latter two species are well established in the Great Lakes of North America, while the records of $P$. hammoniensis from these lakes have shown to be erroneous (Spencer \& Hudson 2003). Another widely distributed, and probably also spontaneously established species in Sweden, P. bedoti (Piguet, 1913), may have remained unnoticed in our rivers, as it mostly reproduces asexually. Additional tubificids of Ponto-Caspian origin are readily dispersing in Eastern and Central Europe but are still unknown from Sweden (Milbrink \& Timm 2001)

Small immature tubificids from Säveån revealing regenerating ends and differing from Potamothrix bedo$t i$ in their chaetae, were tentatively identified as Peipsidrilus saamicus, which is another asexually propagating and therefore cryptic tubificid. It has not been recorded from Sweden before.

Allonais sp., with a single occurrence in Kilaån, remains an enigma, as the genus is largely limited to tropical and subtropical zones. Another naidine taxon, Dero, is also characteristic of warmer conditions. It is represented by two species in our material (one species in Svartån, both species in Kilaån), with $D$. dorsalis here reported from Sweden for the first time. However, other species well known from Europe, such as $D$. $o b$ tusa d'Udekem, 1855 and $D$. (Aulophorus) furcata (Müller, 1774), were not found at all.

Nais behningi was found in a small tributary of Säveån, together with its abundant 'sister' species $N$. alpina. The former is known mainly from large rivers, $N$. alpina from smaller ones. Sometimes it is difficult to distinguish between them, and single individuals with intermediate chaetal shape can occur (Kasprzak \& Szczesny 1976, Timm 1987). The two taxa may represent ecological forms of a single species, and the complex appears to be in need of revision.

Propappus volki (Propappidae) is known as a member of the interstitial fauna in large rivers and lakes, but it has also been found in groundwater (Timm 1987, Timm et al. 1997). The single record in a small inland river of Sweden far from its main range is enigmatic.
This study once more confirms the wide distribution of the lumbriculid Rhynchelmis tetratheca in Sweden, in comparison with its larger congener, $R$. limosella. Several older records of $R$. limosella, and connected with them speculations on this species as a cold-preferring form, apparently are due to misidentifications (Timm et al. 1997).

The leech species found in our rivers are trivial and widely distributed in Northern Europe. Among them, Glossiphonia concolor can be sometimes confused with smooth individuals of $G$. complanata, and therefore its published records may not reflect its actual distribution (Bennike \& Boisen 1943, Lukin 1976, Dall 1982).

Streams and rivers may act as traps for the otherwise terrestrial earthworms (Lumbricidae) repeatedly found as single individuals in the rivers studied. Many earthworms are able to survive several months in soil totally submerged under aerated water (Edwards \& Bohlen 1996). The amphibious Eiseniella tetraedra is an exception, as it thrives in wet soil as well as in shallow water, particularly in cool springs and streams (Timm 1987). In other parts of Europe, there are additional semiaquatic lumbricids (e.g., Helodrilus oculatus Hoffmeister, 1845) that are particularly adapted to oxygen deficiency in decaying mud (Sims \& Gerard 1985), but none of them was found in our material.

Differences between the faunal lists of the separate rivers can be accidental, due to different number of samples or different sampling conditions. This concerns also the relatively high number of species of Naidinae in Kilaån, since none of the naidines recorded only here are otherwise rare. The selection of special sites is important. For instance, in the Kilaån system, two groundwater-bound lumbriculid species (Stylodrilus brachystylus and Trichodrilus sp.) were found at only two of the many sites visited (Ramundsbäcken Stream, and Vretaån River at Vreta, respectively). On the other hand, the Svartån system was largely represented by a single short stretch of the main branch of Svartån (at the old manor site of Karlslund), but this site has optimal conditions for oligochaete diversity (organic enrichment + rapids increasing the oxygen level + macrovegetation). Finding Rhynchelmis limosella only in Svartån can be explained by these conditions, while the single records of Propappus volki and Haber speciosus from the same river may be due to anthropogenic introduction. Presence of Nais behningi, found only in the headwaters of Säveån, could be either a result of a similar introduction, or an identification problem due to obscure relation between two nominal species (see above). 


\section{Conclusion}

The three Swedish river systems studied revealed a clitellate fauna today typical of the once glaciated Northern Europe. However, among a total of 143 species, up to six species (all Enchytraeidae) are new taxa awaiting description, and additionally 12 species have not been recorded from Sweden before. Although there are differences in the composition of the fauna recorded from the rivers, the sampling design does not allow any conclusions regarding a faunistic trend across the country. Instead, it is proposed that the total list of species presented here be regarded as representative of most small-to-medium sized rivers throughout the southern part of the country. The study also showed that the semi-aquatic habitats of river banks may contribute considerably to the total species diversity of invertebrates of a river system.

\section{Acknowledgments}

This is contribution No. 8 of the Swedish Worm (SWORM) Project. We are obliged to U. Pettersson, S. Broberg, M.E. Siddall, K. Lundin, L. Juhlin, I. Brunell, S. Larsson, T. von Proschwitz, and the late I. Hålinder, for assistance in the field work; to N. Funnemark (former head-master), for offering us to use the Stenkullen School as a base while studying Säveån River; to U. Gärdefors for data on Swedish leeches; and to the Swedish Species Information Centre (Contract \# dha 105/02 1.4 to CE), the Olle \& Signhild Engkvists Stiftelse, and the Ebba \& Sven Schwartz' Stiftelse, for financial support.

\section{References}

Bardgett R.D., Anderson J.M., Behan-Pelletier V., Brusaard L., Coleman D.C., Ettema C., Moldenke A., Schimel J.P. \& Wall D.H. 2001. - The influence of soil biodiversity on hydrological pathways and the transfer of material between terrestrial and aquatic ecosystem. Ecosystems, 4, 421-429.

Bennike S. \& Boisen A. 1943. - Contributions to the ecology and biology of the Danish fresh-water leeches (Hirudinea). Folia Limnol. Scand., 2, 1-109.

Berlin, H. 1923. - Untersuchungen , ber Monocystidéen in den vesiculae seminales der schwedischen Oligochaeten. Dissertation, Lund University, Lund, Sweden. Carl Bloms Boktryckeri, Lund, 146 pp, 6 plates.

Brinkhurst R.O. 1978. - Freshwater Oligochaeta in Canada. Can. J. Zool, 56, 2166-2175.

Brinkhurst R.O. 1986. - Guide to the freshwater aquatic microdrile oligochaetes of North America. Can. Spec. Publ. Fish. Aquat. Sci., 84, 1-259.

Chalupsky J. 1992. - Terrestrial Enchytraeidae (Oligochaeta) and Parergodrilidae (Polychaeta) from Sweden, with description of a new enchytraeid species. Zool. Scr., 21, 133-150.

Dall P.C. 1982. - Diversity in reproduction and general morphology between two Glossiphonia species (Hirudinea) in Lake Esrom, Denmark. Zool. Scr., 11, 127-133.

Dózsa-Farkas K. 2002. - Notes on the genus Oconnorella Rota, 1995. Natura Jutl. occas. Pap. Proceedings of the $4^{\text {th }}$ Symposium on Enchytraeidae. Newsletter on Enchytraeidae 7, 2, 86-90.

Edwards C.A. \& Bohlen P.J. 1996. - Biology and ecology of earth- worms. Third edition. Chapman \& Hall, London, 426 pp.

Ekman S. 1915. - Die Bodenfauna des Vättern, qualitativ und quantitativ untersucht. Internat. Rev. ges. Hydrobiol. Hydrogeogr, 7 , 146-204, 275-425.

Erséus C. 2005. - Phylogeny of oligochaetous Clitellata. Hydrobiologia, 535/536, 357-372.

Erséus C., Grimm R., Healy B., Lundberg S., Rota E. \& Timm T. 1999. - Clitellate diversity in Nationalstadsparken, an urban national park in Sweden. Hydrobiologia, 406, 101-110.

Erséus, C. \& Gustavsson L. 2002. - A proposal to regard the former family Naididae as a subfamily within Tubificidae (Annelida, Clitellata). Hydrobiologia, 485, 253-256.

Erséus C., Omodeo P. \& Rota E. 1994. - First records of the allochtonous species Dichogaster saliens and D. bolaui (Oligochaeta: Octochaetidae) from Sweden. Megadrilogica, 6,17-20.

Healy, B. \& Rota E. 1992. - Methods for collecting enchytraeids during expeditions. Soil Biol. Biochem., 24, 1279-1281.

Holmquist C. 1975. - Maskar i dricksvattnet - en för Sverige okånd oligochaet (fåborstmask) avslöjad. Fauna Flora Stockh., 70, 193197. [In Swedish with English summary.]

Hynes H.B.N. 1970. - The ecology of running waters. Liverpool University Press, Liverpool, 555 pp.

Julin E. 1949. - De svenska daggmaskarterna. Ark. Zool., 42, 1-58. [In Swedish.]

Kasprzak K. \& Szczesny B. 1976. - Oligochaetes (Oligochaeta) of the River Raba. Acta Hydrobiol. (Kraków), 18, 75-87.

Kirkegaard J.B. 1985. - Ferskvandsigler. Danmarks Fauna, Vol. 82. Dansk Naturhistorisk Forening, Copenhagen, 80 pp.

Kristjánsson B.K. \& Svavarsson J. 2004. - Crymostygidae, a new family of subterranean freshwater gammaridean amphipods (Crustacea) recorded from subarctic Europe. J. Nat. Hist., 38, 18811894.

Lukin E.I. 1976. - Pijavki, I. Fauna SSSR, n.s. No 109. Nauka, Leningrad, 484 pp. [In Russian.]

Milbrink G. 1969. - On the composition and distribution of oligochaetes in Lake Vättern 1967-1968. Rep. Inst. Freshw. Res. Drottningholm, 49, 149-156.

Milbrink G. 1970. - Records of Tubificidae (Oligochaeta) from the great lakes (L. Mälaren, L. Vättern, and L. Vänern) of Sweden. Arch. Hydrobiol., 67, 86-96.

Milbrink G. 1973. - On the use of indicator communities of Tubificidae and some Lumbriculidae in the assessment of water pollution in Swedish lakes. Zoon, 1, 125-139.

Milbrink G. 1978. - Indicator communities of oligochaetes in Scandinavian Lakes. Verh. Internat. Ver. Limnol., 20, 2406-2411.

Milbrink G. 1980. - Oligochaete communities in pollution biology: The European situation with special references to lakes in Scandinavia. Pages 433-455 in Aquatic oligochaete biology. Brinkhurst R.O. \& Cook D.G. (eds). Plenum Publishing Corporation, New York.

Milbrink G. 1993. - Evidence for mutualistic interactions in freshwater oligochaete communities. Oikos, 68, 317-322.

Milbrink G. 1999. - Distribution and dispersal capacity of the Ponto-Caspian tubificid oligochaete Potamothrix heuscheri (Bretscher, 1900) in Scandinavia. Hydrobiologia, 406, 133-142.

Milbrink G. \& Timm T. 2001. - Distribution and dispersal capacity of the Ponto-Caspian tubificid oligochaete Potamothrix moldaviensis Vejdovsky et Mrázek, 1903 in the Baltic Sea Region. Hydrobiologia, 463, 93-102.

Milbrink G., Timm T. \& Lundberg S. 2002. - Indicative profundal oligochaete assemblages in selected small Swedish lakes. Hydrobiologia, 468, 53-61.

Naiman R.J. \& Décamps H. 1997. - The ecology of riparian interfaces: riparian zones. Ann. Rev. Ecol. Syst., 28, 621-658. 
Nielsen C.O. \& Christensen B. 1959. - The Enchytraeidae. Critical revision and taxonomy of European species. Natura Jutl., 8-9, 1160.

O'Connor F.B. 1955. - Extraction of enchytraeid worms from a coniferous forest soil. Nature, 175, 815-816.

Piguet E. 1919. - Wasserbewohnenden Oligochaeten der nordschwedischen Hochgebirge. Naturwiss. Untersuch. Sarekgeb. Schwed.Lappl. 4 (Zool. 7), 778-801.

Popcenko V.I. 1988. - Vodnye maloscetinkovye cervi Severa Evropy. Nauka, Leningrad, 287 pp. [In Russian.]

Rota E. \& Erséus C. 1997. - First record of Dendrobaena attemsi (Michaelsen) (Oligochaeta, Lumbricidae) in Scandinavia, with a critical review of its morphological variation, taxonomic relationships and geographical range. Ann. Zool. Fenn., 34, 89-104.

Rota E. \& Healy B. 1999. - A taxonomic study of some Swedish Enchytraeidae (Oligochaeta), with descriptions of four new species and notes on the genus Fridericia. J. nat. Hist., 33, 29-64.

Rota E., Healy B. \& Erséus C. 1998. - Biogeography and taxonomy of terrestrial Enchytraeidae (Oligochaeta) in Northern Sweden, with comparative remarks on the genus Henlea. Zool. Anz., 237, 155-169.

Schmelz R.M. 2002. - Records and taxonomy of Fridericia species found in the Mols area. Natura Jutl. occas. Pap. (Proceedings of the $4^{\text {th }}$ Symposium on Enchytraeidae, Newsletter on Enchytraeidae 7), 2, 75-85.

Schmelz R.M. 2003. - Taxonomy of Fridericia (Oligochaeta, Enchytraeidae). Revision of species with morphological and bioche- mical methods. Abh. naturwiss. Ver. Hamb. (N. F.), 38, 1-414, +73 figures.

Siddall M.E. 2002. - Phylogeny of the leech family Erpobdellidae (Hirudinida: Oligochaeta). Invert. Syst., 16, 1-6.

Sims R.W. \& Gerard B.M. 1985. - Earthworms. Synopses of the British Fauna (New Series) 31. E.J. Brill \& W. Backhuys, London etc., $171 \mathrm{pp}$.

Spencer D.R. \& Hudson P.L. 2003. - The Oligochaeta (Annelida, Clitellata) of the St. Lawrence Great Lakes Region: an update. $J$. Great Lakes Res., 29, 89-104.

Springett J.A. 1971. - The Enchytraeidae (Oligochaeta) of South Western Australia: the genus Fridericia Michaelsen 1889. J. R. Soc. West. Austr., 54, 17-20.

Southern R. 1907. - Oligochaeta of Lambay. Ir. Natural. J., 16, 6882.

Timm T. 1987. - Maloöcetinkovye cervi (Oligochaeta) vodoemov Severo-Zapada SSSR. Valgus, Tallin, 299 pp. [In Russian, with English Summary.]

Timm T., Erséus C.\& Lundberg S. 1997. - New and unusual records of freshwater Oligochaeta from the Scandinavian Peninsula. Nord. J. Freshw. Res., 72, 15-29.

Wood P.J. \& Proudlove G.S. 2004. - Subterranean biodiversity in Great Britain and Ireland: a predominantly post-glacial colonising fauna with possible trans-glacial elements. Symposium on World Subterranean Biodiversity, Pascalis Project, Villeurbanne, 8-10 December 2004. Book of Abstracts: 46. 